Research Article

\title{
Effect of fillet thickness on quality and shelf life of gravlax salmon
}

\begin{abstract}
Gravlax Atlantic salmon is a raw fish product typically stored at chill temperatures that will go through no further heat processing before consumption. Bacterial spoilage can reduce shelf life while pathogens can represent a serious hazard for susceptible consumers. This experiment was conducted to provide an estimate of the shelf life of 2 thicknesses of gravlax salmon stored at $4^{\circ} \mathrm{C}$ by monitoring, $\mathrm{pH}$, water activity $\left(\mathrm{a}_{\mathrm{w}}\right)$, salt levels over a 21 day period and microbial numbers (TPC) over 41 days. Total plate counts for both the $1 \mathrm{~cm}$ and $2 \mathrm{~cm}$ thicknesses remained at less than $104 \mathrm{CFU} / \mathrm{g}$ at the conclusion of the experiment on day 41 . Salt levels were $11.41 \%$ and $6.85 \%$ and water activity values 0.83 and 0.85 for 1 and $2 \mathrm{~cm}$ thicknesses respectively. From these figures it was concluded that both the 1 $\mathrm{cm}$ and $2 \mathrm{~cm}$ thicknesses of gravlax treated Atlantic salmon stored at $4^{\circ} \mathrm{C}$ have shelf- lives longer than 41 days.
\end{abstract}

Volume 6 Issue 2 - 2017

\author{
Karzan F Namiq, David Milne \\ Sulaimani polytechnic university, Iraq
}

Correspondence: Karzan F Namiq, Sulaimani polytechnic university, Iraq, Email karzan.fatih@gmail.com

Received: March 29, 2017| Published: August 07, 2017

\section{Introduction}

Fish is vital source of animal protein and other elements for healthy body maintenance. ${ }^{1}$ Fish also provides a good source of high quality protein and contains many minerals and vitamins. It is susceptible to spoilage and quality loss can happen very quickly after catch. ${ }^{2-5}$

There is an increasing demand for fish and fish products around the world. ${ }^{5}$ Seafoods have traditionally been popular in many countries as an alternative source of animal protein. ${ }^{6}$ Nowadays, more people are returning to seafood as a healthy alternative to red meat. The low fat content in many fish species (white fleshed, demersal) has positive impacts on coronary heart disease due to the $n-3$ polyunsaturated fatty acids. This is particularly important for health of conscious people especially in affluent countries, where heart disease mortality is high. ${ }^{6}$

Despite many advantages of seafood consumption, it has disadvantages such as causing disease due to microbial infection or intoxication. ${ }^{6}$ Also, seafood varies from other types of food in many ways, the majority of seafoods are still extracted from a wild population. The processors of wild catch seafood are limited in their choices of raw material to what is available in respect of size, condition and species of fish landed by fishermen. ${ }^{6}$

Certain pre-packed, ready to eat foods with long shelf life stored at refrigerated food temperatures are of high risk because of Listeria monocytogenes. ${ }^{7,8}$ These products will be eaten without additional heat treatment and therefore represent a significant risk to selected consumers (young, old, pregnant and immune compromised). Examples for these foods are cold smoked and gravlax (gravid) from salmon and rainbow trout. ${ }^{9}$

There are many ways to spell and pronounce of gravlax such as gravid laks, gravid lax, graflax. ${ }^{10}$ All of them related to the Nordic dish of cured raw salmon. Gravlax is translated from the Swedish as buried salmon- grav means grave and lax means salmon that referred to the old custom of salting salmon or other freshly caught fish. After salting fish were left to cure in the ground at temperatures near $0^{\circ} \mathrm{C} .{ }^{10}$ Ultra -fresh salmon is clearly important for making gravlax for both food safety reasons and to ensure the best taste and texture (quality). ${ }^{10}$ Gravlax products are produced by rubbing salmon fillets with a mixture of sugar, salt, pepper and covered with the herb dill and stored at refrigerated temperatures to cure for up to 2 days in plastic bags. ${ }^{9}$
Salt in the cure acts in three ways, firstly, salt restricts the growth of some species of bacteria and extends the stability and shelf life of salmon. It also reduces water activity by osmosis, creating a denser texture and it tenderizes salmon by breaking down the structure of protein. ${ }^{10}$

There are many problems concerning the safety of seafood. Seafood is generally made unsafe because of the existence of pathogenic microorganisms, which can take place naturally or can be transmitted to the seafood after it is caught by contamination with people. ${ }^{11}$ Pathogenic bacteria, which are normally associated with human or warm blooded animals and their faeces, and not normally present in fish or seafood products include Listeria monocytogenes, Salmonella, Escherichia coli and Stapylococcus aureus. ${ }^{12-13}$ Seafood is more perishable than other high protein products because of the high level of soluble nitrogen compounds in the tissue. ${ }^{14}$ Activities of microbes are responsible for changes in flavor, odor, texture and color. All sea foods are susceptible to environmental contaminants, including pathogens from harvesting and on board ship handling process. ${ }^{14}$ Until recently the microbiological safety of seafood was made certain by testing final products at a laboratory. ${ }^{11}$ Final product testing was very costly and of limited value. ${ }^{11}$ A new system was developed that relied on the assessment of microbiological hazards related to the products. This system called Hazard Analysis Critical Control Point (HACCP) system, which is being adopted right through the world. ${ }^{11}$

Shelf life of food can be defined as the maximum length of time a given product is suitable for human consumption. ${ }^{15}$ In seafood market, fresh and frozen shelf life is a very vital consideration. Knowing the remaining shelf life is very important and allows the processor and retailer to plan the length of time a product can be stored. ${ }^{15}$ Extended shelf life allows control of the market and reduces waste. By adding to the shelf life allows the market to achieve better economic returns and ensure quality. ${ }^{15}$ The shelf life of fish could be determined by physical, chemical and microbiological analysis. ${ }^{16}$

The shelf life of fish products is usually restricted by microbial activities that are affected most importantly by storage temperature. ${ }^{17,18}$ Typically the shelf life of fish fillets that are kept at chill temperatures ranges between 7 to 14 days (depending on species, harvest location and season). ${ }^{19,20}$ In Australia chilled seafood competes with other fresh protein products. The customer during purchase relies on sight 
and smell for giving indications of future eating performance..$^{21}$ In addition, consumers are progressively demanding more consistently high quality food, and have expectations that such quality will be kept at a high level during the period from production to consumption. ${ }^{22,23}$

Temperature is the most important factor in determining the shelf life of fish. ${ }^{6}$ The rate of bacterial spoilage and enzyme breakdown is mediated by temperature. ${ }^{15}$ Quality of fish is strongly affected by the time and temperature between harvest and consumption as temperature impacts both bacterial growth and autolysis. ${ }^{24}$ Therefore, time alone will not provide a good indication of freshness and product quality. ${ }^{25,26}$ Small changes of temperature in the range of 0 to $10^{\circ} \mathrm{C}$ have a major influence on microbiological growth. ${ }^{6}$ This range is also similar to that found in refrigerated storage systems. Most microbes are incapable of growth at temperatures below $5^{\circ} \mathrm{C}$ but Listeria monocytogenes has been documented growing at chill temperatures of $4^{\circ} \mathrm{C}$.

Many traditional preservation methods have been developed using salt and sugar to control microbial growth. Water is necessary for survival and growth of microorganisms. ${ }^{27}$ The preservation process results from the addition of salt to a food product causing an imbalance and by osmosis, dehydration results. ${ }^{27}$ The mass transfer mechanism of salt has two major fluxes. First, loss of water in fish products is due to the osmotic phenomena. Second, flow of water from lower salt concentration zones (inside food) to higher salt concentration zones (outside food), dissolving salt. ${ }^{28}$ In addition salt levels in the flesh correspondingly increase. Salt concentration in the flesh is very important. Elevated salt levels greater than $10 \%$ will be sufficient to restrict the growth of clostridium botulinum and the majority of pathogens and spoilage bacteria.

The consequence of adding salt and sugar is a reduction of water activity which is a measure of unbound, free water molecules in food products. The range of water activity is between zero (water absent) and 1.0 (pure water). ${ }^{29}$ Shelf stability can be determined through water activity unlike water content. It can predict which microorganism will be possible sources of spoilage and infection due to their water requirements.

Sugar is used in gravlax to offset the taste associated with elevated salt levels in the flesh. While sugar is most commonly used to preserve confections it also decreases the amount of free water available (water activity) for growth of microbes Smith and Stratton, 2007. High levels of sugar are effective in preventing the growth of yeasts and molds. Salt is more effective weight for weight than sugar as salt ionizes to a sodium cation and chloride anion attracting a sheath of water molecules. These ionically related molecules of water are unavailable for use by microorganisms and there is a propensity for the ionic forces to dehydrate microbial cells. ${ }^{30}$

The aim of this study was to estimate the quality of salmon gravlax shelf life at 1 and $2 \mathrm{~cm}$ thick of fillets, to note changes in $\mathrm{pH}$ (chemical analysis), to observe microbial growth (microbiological analysis: TPC) and to note changes in water activity.

\section{Materials and methods}

\section{Experimental design}

This study sought to establish the shelf life of different thicknesses of Atlantic salmon gravlax stored at a mean temperature of $4{ }^{\circ} \mathrm{C}$. Skinless Atlantic salmon fillet portions were allocated to treatments based on mean thicknesses of 1 and $2 \mathrm{~cm}$ before treating with salt, sugar and fresh dill. Analytical tests included flesh salt content measured on day $2, \mathrm{pH}$ and water activity $\left(\mathrm{a}_{\mathrm{w}}\right)$ until day 21 and microbiological total plate count (TPC) tests until day 41 .

\section{Fish harvesting}

Atlantic salmon (Salmo salar) were grown at the aquaculture center at the university of Tasmania and harvested in July 2015 before being transported to the Australian Maritime College (AMC), Beauty Point seafood laboratory. At harvest fish were first treated with a fatal dose of sedative. Unconscious fish were removed from the tanks before receiving a blow to the head as per animal ethics guidelines. Whole fish were repacked before freezing at Beauty Point.

\section{Facility preparation}

Before starting fish processing, all surfaces, processing facilities, tools and materials (cutting board, tray, scale, bench and knife), were cleaned by using detergent (Tiger Plus, Applied Chemicals-Forming alkaline, chlorinated detergent). At the conclusion of cleaning, facilities were then disinfected with a commercially obtainable quaternary ammonium compound (FS Formula 7000, Calman Australia) used at a dilution of 500: 1 as suggested in the manufacturer's instructions

\section{Fish processing}

Whole fish were frozen and stored at $-25^{\circ} \mathrm{C}$ until use. In this experiment 10 fish with an average whole weight of $1.1689 \mathrm{~kg} \pm 0.075$ were used. Frozen fish were thawed in a chiller set at $4{ }^{\circ} \mathrm{C}$ for 2 days before weighing, gutting, and filleting. Whole salmon fillets were trimmed of visible lateral fat before the removal of pin-bones and final rinsing. Fillets were allocated to 1 and $2 \mathrm{~cm}$ thickness treatments.

\section{Marinating process}

Fresh filleted salmon were rinsed gently, and patted mostly dry using paper towel. Salmon fillets were put on a tray, salt, sugar and dill were shaken over the fillets before wrapping in a layer of plastic. Fillets were subsequently further tightly wrapped in at least two more layers of plastic: one around the middle and one lengthwise to prevent leakage and remove air gaps. Wrapped fillets were well mixed with the curing mixture so all surfaces of the fish received an even cure. Final products were vacuum packed (model COMPACK Kramber Greb, Germany). Packed fillets were put in the refrigerator at $4^{\circ} \mathrm{C}$ and turned over morning and evening for $48 \mathrm{hr}$. Recipes of the fish, salt and sugar ratios for $1 \mathrm{~cm}$ and $2 \mathrm{~cm}$ thick gravlax are presented in (Table 1).

Table I Recipes for I and $2 \mathrm{~cm}$ fillet thicknesses of gravlax salmon

\begin{tabular}{llll}
\hline I Cm Thick fillet recipe & \multicolumn{3}{l}{ 2 Cm Thick fillet recipe } \\
\hline Ingredients & Ratio & Ingredients & Ratio \\
Fillet $(\mathrm{Icm})$ & $1000 \mathrm{~g}$ & Fillet $(2 \mathrm{~cm})$ & $1000 \mathrm{~g}$ \\
Salt & $200 \mathrm{~g}$ & Salt & $200 \mathrm{~g}$ \\
Sugar & $100 \mathrm{~g}$ & Sugar & $100 \mathrm{~g}$ \\
Fresh dill & $\mathrm{I}$ bunch & Fresh dill & I bunch \\
\hline
\end{tabular}

\section{Microbial analysis}

A total aerobic plate count (TPC) method (AOAC, 2000) was used to analyze microbial quality, according to AOAC official methods with some changes. Changes included incubation temperature of $25^{\circ} \mathrm{C}$ as suggested by the ICMSF for aerobic plate counts (APC) of seafood products (ICMSF, 1986). ${ }^{31}$ In addition, sample volumes were decreased proportionally because of the capacity of the stomacher. Around 10 gram of product for every treatment was put into the stomacher and weighted. Sterile water $(90 \mathrm{~mL})$ was added to the bag and both were stomached for 1.3 minute (Stomacher - Lab Blender 400 , London). Serial dilutions for each replicate were prepared in Macartney bottles containing $9 \mathrm{ml}$ of sterile $0.5 \%$ peptone water. Pour 
plates were prepared with $1 \mathrm{ml}$ for each dilution transferred to 900 $\mathrm{mm}$ petri dishes.

Plate Count Agar was prepared according to the manufactures instructions and was tempered in a water bath at $48^{\circ} \mathrm{C}$. All pour plates were incubated at $25^{\circ} \mathrm{C}$ for 48 hours or until recognizable colonies could be identified. Some days, incubation periods were extended to 120 hours due to the colonies slow growth. Means of 2 replicates are shown as colony-forming units for gram of muscle (CFU/g).

\section{Water activity $\left(a_{w}\right)$}

Water activity was determined by using Novasina $\mathrm{a}_{\mathrm{w}-}$ center, which was calibrated at $25{ }^{\circ} \mathrm{C}$ by using sodium chloride (water activity 75.3) and magnesium chloride (32.5 water activity) before placing samples into it. $10 \mathrm{~g}$ of gravlax was ground in a mortar and pestle until a homogenous mixture were achieved. $5 \mathrm{~g}$ of samples (gravlax) were placed in capsules until readings stabilized with four arrow bars recorded for each sample.

\section{Salts}

Salt content tests were done on day 2 of the experiment using AOAC standard method $937.09,{ }^{32}$ after maturing of gravlax for 48 hours. Gravlax products were taken out of the cold room $\left(4{ }^{\circ} \mathrm{C}\right)$ and rinsed with water to remove salts from both groups. $10 \mathrm{~g}$ sample was ground with a mortar and pestle until a homogenous mixture was achieved. $2 \mathrm{~g}$ samples were weighed into flasks by using an analytical balance (HF-300 G) and $50 \mathrm{~mL}$ of standardized $\mathrm{AgNO}_{3}(0.1006 \mathrm{M})$ added to every flask. Subsequently $10 \mathrm{~mL}$ of aliquot of $\mathrm{HNO}_{3}$ was added to the samples and heated on a hot plate in the fume hood until digestions of samples were completed. Samples were cooled down for 15 minutes prior to add $50 \mathrm{~mL}$ of deionised water to both flasks. Finally a $3 \mathrm{~mL}$ aliquot of $\mathrm{FeNH}_{4}\left(\mathrm{SO}_{4}\right)_{2} 12 \mathrm{H}_{2} \mathrm{O}$ indicator was added to every flask and titrated (0.1 M NH4SCN) until a brown color change was noted. Values of salt content were calculated to obtain a mean salt content of the gravlax.

Calculation used:

1. $\mathrm{N}(\mathrm{NaCl})=\left[\left(\mathrm{Vol}, \mathrm{AgNO}_{3}(\mathrm{ml})-\right.\right.$ Vol.titre $\left.(\mathrm{ml}) \times 10^{-3}\right] \times$ Conc. $\mathrm{AgNO}_{3}(\mathrm{M})$ (moles)

2. $\mathrm{M}(\mathrm{NaCl})=\mathrm{n}(\mathrm{NaCl}) \times 58.44(\mathrm{MW}$ of $\mathrm{NaCl})($ grams $)$

3. Salt content $(\%)=[\mathrm{m}(\mathrm{NaCl}) /$ Mass of sample $(\mathrm{g})]$ x 100

\section{pH measurement}

The $\mathrm{pH}$ for each sample was taken and measured by using a $\mathrm{pH}$ meter (WTW PH 330, Weilheim Germany) in arrangement with internal (WTW Sentix SP) electrode. The $\mathrm{pH}$ meter was calibrated using buffers at 7.0 and 4.0 before use. $\mathrm{pH}$ readings of flesh were taken by entirely inserting the glass tip of the WTW Sentix SP electrode into the flesh as per the method of Thomas. ${ }^{33}$

\section{Statistical analyses}

Statistical analysis for this experiment was conducted by using SPSS 22 for windows. All graphs in this experiment were presented as mean values \pm standards error mean (SEM).Differences between means were assumed to be significant at $P<0.05$.

\section{Results}

\section{Microbial analyses}

Total aerobic plate counts (TPC) were conducted on days $0,2,5$,
$8,12,15,18,21,32,41$ and presented in (Figure 1). The TPC for raw material on day 0 for both thin and thick treatments ( 1 and $2 \mathrm{~cm}$ thick fillets) was a mean $(\mathrm{n}=2)$ of 500 and $600(\mathrm{CFU} / \mathrm{g})$, respectively. On day 2 after curing mean microbial loads were 420 and 630 (CFU/g). Counts increased slowly and by day 21 microbial loads had increased to 960 for $1 \mathrm{~cm}$ thick and $1300(\mathrm{CFU} / \mathrm{g})$ for $2 \mathrm{~cm}$ thick treatments. On day 41 at the end of monitoring microbial loads had increased to 1380 for $1 \mathrm{~cm}$ thick and $3497(\mathrm{CFU} / \mathrm{g})$ for $2 \mathrm{~cm}$ thick gravlax fillets.

\section{Water activity}

Water activity $\left(\mathrm{a}_{\mathrm{w}}\right)$ values were measured on days $0,5,8,12,15$, 18 and 21 and are presented in (Figure 2). The values of $\mathrm{a}_{\mathrm{w}}$ on day 0 (raw fillets) were $0.911 \pm 0.002$ for $1 \mathrm{~cm}$ thick fillets and $0.92 \pm$ 0.0021 for $2 \mathrm{~cm}$ thick fillets. On day 5 after treatment $\mathrm{a}_{\mathrm{w}}$ values for both treatments had decreased to a mean of 0.83 and 0.85 for the $1 \mathrm{~cm}$ thick and $2 \mathrm{~cm}$ thick fillets. Water activity subsequently increased for the rest of the experiment, reaching $0.849 \pm 0.0015$ for $1 \mathrm{~cm}$ thick and $0.859 \pm 0.0010$ for $2 \mathrm{~cm}$ thick on day 21 .

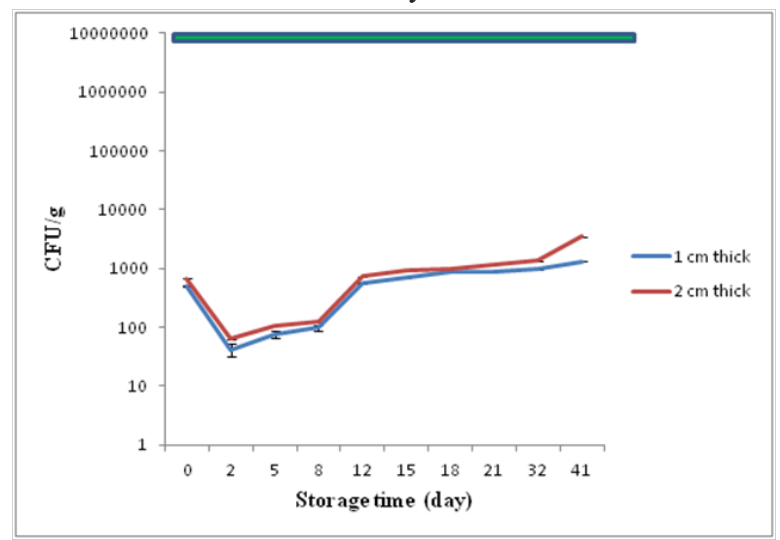

Figure I Mean TPC ( \pm SEM) for I and $2 \mathrm{~cm}$ thick fillets sampled on $0,2,8$, $15,21,32$ and 4 I days, ICMSF (I986) standard of $10^{7} \mathrm{CFU} / \mathrm{g}$ is indicated by the green line.

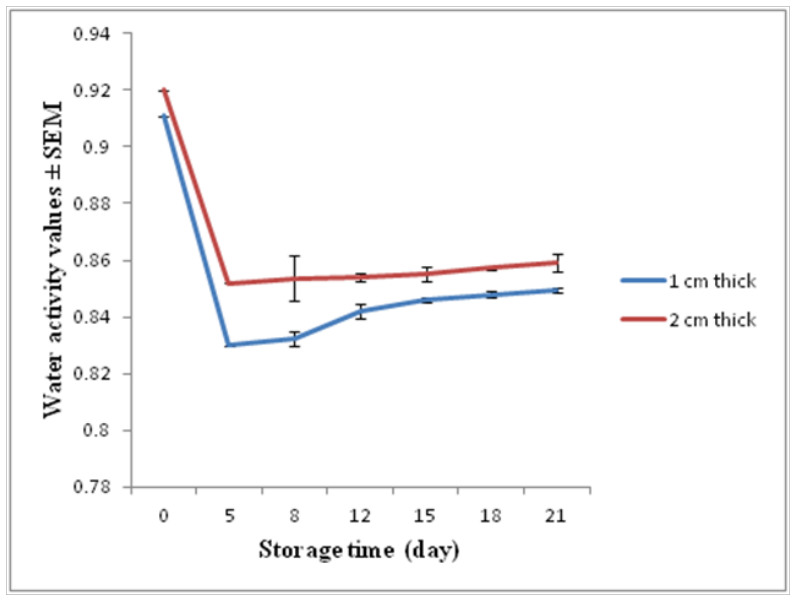

Figure 2 Mean water activity $\left(a_{w}\right)( \pm S E M)$ for I and $2 \mathrm{~cm}$ thick fillets sampled on $0,2,8,15$ and 21 days.

\section{Salt}

Salt content measurements were done on day 2 of the experiment after rinsing residual salt from the treatments with fresh water and drying with absorbent paper. 3 replicates for each fillet thickness were measured, the mean calculated and shown in (Figure 3). Salt content for each treatment is presented as a percentage. The percentage of 
salt in the $1 \mathrm{~cm}$ thick fillets was $11.41 \%( \pm 1.45)$ and approximately double that of the $2 \mathrm{~cm}$ thick fillets at $6.85 \%( \pm 0.40)$.

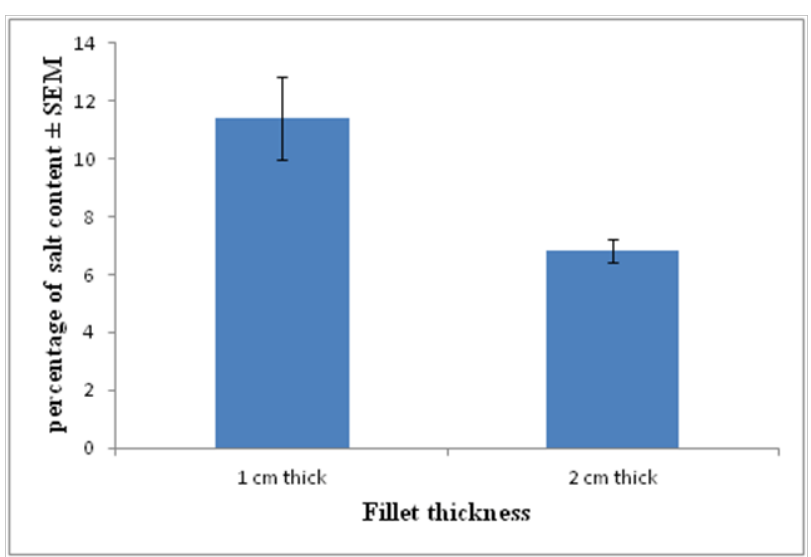

Figure 3 Mean $(n=3)$ salt content $( \pm$ SEM) of I and $2 \mathrm{~cm}$ thick fillets sampled on day 2 of the experiment.

\section{pH}

$\mathrm{pH}$ was measured on days $0,2,8,15$ and 21 of the experiment. The day $0 \mathrm{pH}$ of raw fillets before curing was $6.23 \pm 0.005$ for $1 \mathrm{~cm}$ thick fillets and $6.35 \pm 0.06$ for $2 \mathrm{~cm}$ thick fillets. On day $2 \mathrm{pH}$ values had decreased for both treatments reaching $5.65 \pm 0.055$ and $5.83 \pm 0.055$ for 1 and $2 \mathrm{~cm}$ thick fillets respectively. From day 2 until day $21 \mathrm{pH}$ values increased slightly and reached $5.7 \pm 0.005$ for $1 \mathrm{~cm}$ thick and $5.87 \pm 0.03$ for $2 \mathrm{~cm}$ thick at the conclusion of the experiment. There was a significant difference in $\mathrm{pH}$ between the 2 different thicknesses of gravlax fillets (Figure 4).

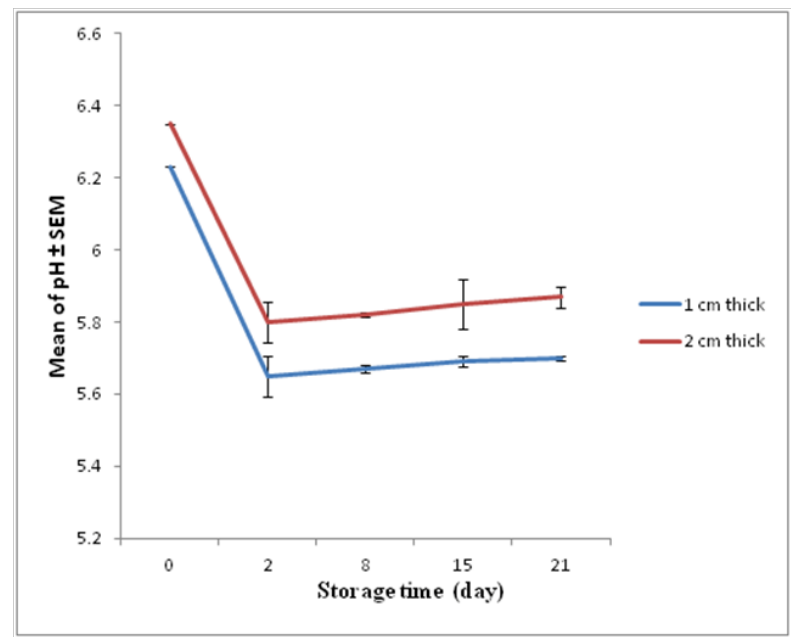

Figure 4 Mean muscle $\mathrm{pH}(\mathrm{n}=5)$ of $( \pm$ SEM) I and $2 \mathrm{~cm}$ thick fillets sampled at $0,2,8,15$ and 21 days.

\section{Discussion}

In general, shelf life is quoted in terms of storage time in days before sensory rejection. Associated with sensory rejection are microbial and chemical parameters that individually or in combination provide indicators to spoilage. ${ }^{19,20}$ In Australia, there is no indicative microbial standard for the shelf life of chilled seafood but the maximum safe limits for Total Plate Counts (TPC) are generally agreed at between 5 x $10^{6} \mathrm{CFU} / \mathrm{g}$ (AQIS) to $10^{7} \mathrm{CFU} / \mathrm{g}$ (ICMSF).

Initial microbial loads after processing were low and indicate fresh fish and sanitary processing conditions. After curing with salt and sugar microbiological loads in both thin and thick fillets remained close to initial counts. Between days 2 and 30 microbial counts for both treatments remained similar before counts of the thin fillets exhibited accelerated growth after day 30 . The lack of difference in microbial growth between the two treatments can related to the salt and sugar contents in both.

In microbial terms both $1 \mathrm{~cm}$ and $2 \mathrm{~cm}$ thick fillets exhibited shelflives in excess of 41 days at which time counts for both treatments were less than $10^{4} \mathrm{CFU} / \mathrm{g}$. These numbers are significantly less than the $10^{6}$ (AQIS) and $10^{7}$ (ICMSF) maximum safe limits recommended for chilled fish products. The basis for this extended shelf life at a storage temperature of $4^{\circ} \mathrm{C}$ may be attributed to the salt levels in the flesh and associated $\mathrm{a}_{\mathrm{w}}$ of the gravlax fish. The ratio of 10:2:1 fish to salt and sugar at the brine time of $48 \mathrm{hr}$ resulted in residual salt levels of $6.85 \%$ and $11.41 \%$ and water activities of 0.85 and 0.83 respectively for $1 \mathrm{~cm}$ and $2 \mathrm{~cm}$ thick fillets.

Table 2 lists growth factors for a range of typical spoilage, pathogenic bacteria, molds and yeasts. In summary the combination of storage temperature, salt and water activity of the gravlax Atlantic salmon would prevent the growth of all organisms listed in Table2.

Table 2 Growth factors for spoilage, pathogen bacteria and other (mold and yeast) (Ratkowsky et al. ${ }^{38}$ Food and Drug Administration ${ }^{42}$

\begin{tabular}{|c|c|c|c|c|}
\hline Spoilage & Salt (\%) & $a_{w}$ & Temp ${ }^{\circ} \mathrm{C}$ & $\mathrm{pH}$ \\
\hline Pseudomonas spp. & $0-10$ & $0.94-0.95$ & $15-40$ & $4-9$ \\
\hline E.coli & $0-5$ & $0.91-0.99$ & $7-40$ & $4-7$ \\
\hline Enterobacteriaceae & $0-6.5$ & $0.94-0.95$ & $8-44$ & $3.8-9$ \\
\hline Lactic acid bacteria & $1-10$ & $0.91-0.99$ & $8-44$ & $4-7$ \\
\hline \multicolumn{5}{|l|}{ Pathogen } \\
\hline Staphylococcus aureus & $0-25$ & $0.83-0.99$ & 7- 47.8 & $4.5-9.3$ \\
\hline L. monocytogenes & $0-14$ & $0.90-0.99$ & $0-45$ & $4-9.6$ \\
\hline \multirow[t]{2}{*}{ E.coli pathogenic } & $0-5$ & $0.94-0.95$ & 7-44 & $4-9$ \\
\hline & Other & & & \\
\hline Mold & & $0.7-0.80$ & $10-35$ & $2-9$ \\
\hline Yeasts & & $0.87-0.94$ & $0-47$ & $2-9$ \\
\hline
\end{tabular}

The gravlax water activity is sufficiently low to prevent the growth of all listed bacteria both spoilage and pathogenic with molds being the only organism capable of surviving at the measured levels for both thicknesses.

Residual salt levels were sufficient in the thin fillets to eliminate all spoilage organisms excluding Pseudomonas spp. and Lactic acid bacteria. Only Listeria monocytogenes a pathogen would be capable of growth at the residual salt levels. For the thick fillets salt levels were either sufficient or at the margins for growth of nearly all bacterial organisms excluding Listeria monocytogenesand Staphylococcus aureus.

Storage temperature was sufficient to prevent the growth of all organisms except Listeria monocytogenes. The inhibitory effects of the product and storage parameters should prevent the growth of all the listed organisms and explain the long lag phase observed for both thicknesses. At day 41 microbial growth was only $\log 2$ above initial counts indicating additional time would be required to reach maximum numbers for product safety.

Salting of fish products decreases water activity $\left(a_{w}\right)$, therefore, it prevents growth many of spoilage microorganisms. ${ }^{34,35}$ In addition, the chloride ion is toxic for many microorganisms. ${ }^{36}$

There was a significant difference between the salt concentrations of thin and thick fillets $6.85 \% \pm 0.40$ and $11.41 \% \pm 1.44$ respectively. 
The difference in salt uptake between thin and thick fillets is confirmed by $\mathrm{FAO},{ }^{37}$ which reported that thick filleted fish tend to absorb salt slower than thin fillets. The relative rate of salt uptake also decreases with fillet thickness with the uptake slowing towards the center of fillets. Piggot and Tucker ${ }^{38}$ also reported factors that affect salt absorption include: grain size, purity of salt and the thickness of the flesh.

The salt levels recorded in the thick gravlax product are at the upper end of that in which most microbial organisms will grow. ${ }^{6}$ This combined with the low water activity and chill storage temperatures while sub lethal to many bacteria would in combination result in metabolic stress and an inability to grow. ${ }^{39}$ In thin fillets the salt levels measured would preclude the growth of all but halotolerant bacteria including Staphylococcus aureus and Listeria monocytogenes.

In general bacteria are more sensitive than molds and yeasts to reduced water activity and approximately all are prevented from growth at water activities less than 0.90 to 0.91 while molds and yeasts grow at $0.7-0.80$ and $0.87-0.94$ respectively. ${ }^{40}$

Initial water activity $\left(a_{w}\right)$ values in frozen defrosted raw flesh were 0.91 and 0.92 . These values were lower than typical water activities observed in fresh flesh of 0.95 to 0.99 (Fraser, 1998). These values may be influenced by the high oil content and slow freezing of the raw material that was used for the gravlax. Slow freezing is associated with post freezing driploss while high oil levels in the salmon flesh result in lower water activities. ${ }^{6}$

Reductions in $\mathrm{a}_{\mathrm{w}}$ values are the result of osmotic imbalance due to the addition of salt and sugar in the brine. Water flows from low salt concentration to high concentration zones resulting in less water in the fish flesh. ${ }^{28}$ Water activity values after curing were significantly lower at 0.83 and 0.85 in thin and thick fillets, respectively. These values were in the range 0.75 to 0.85 reported for cured fish products by Piggot and Tucker. ${ }^{38}$

$\mathrm{pH}$ in this study was used to confirm microbial total plate count numbers. Generally increases in microbial numbers are associated with increases in $\mathrm{pH}$ values. In this study the small increases in $\mathrm{pH}$ over time confirms the relatively small increases in microbial counts.

Initial $\mathrm{pH}$ values for both fillets (thin and thick) were 6.23 and 6.35 , respectively. These values were in agreement with Asli et al., ${ }^{41}$ who noted the $\mathrm{pH}$ value of flesh salmon as 6.46 before any treatment. In day 2 of experiment (after curing) $\mathrm{pH}$ values were significantly decreased in both fillets thicknesses, 5.65 thin and 5.83 thick. Finally, the low $\mathrm{pH}$ values impact the water-holding ability of the muscle, resulting in increased exudate loss that is related to as driploss. ${ }^{42-50}$

\section{Conclusion}

In this experiment gravlax salmon were stored for 41 day, during in this period microbial loads did not exceed $10^{4} \mathrm{CFU} / \mathrm{g}$ and was well below the indicative standard of $107 \mathrm{CFU} / \mathrm{g}$ (ICMSF). From these figures it may be extrapolated that the shelf life of gravlax should be longer than 45 days. It could be expected that the thin variant would have a longer shelf life than the thick due to the lower water activity and higher salt content. This product had much longer shelf life than fresh fillet of salmon, which is 15 days at $4 \mathrm{oC}$, while gravlax had 45 days shelf live at $4 \mathrm{oC}$. Longer shelf live would help waste reduction of gravlax due to spoilage, can be stored for long time at stores and long chain of distribution.

\section{Acknowledgments}

None.

\section{Conflicts of interest}

None.

\section{References}

1. Ravichandran S, Joseph FRS, Kanagalakshmi R, et al. Variation in Nutritive Composition of Two Commercially Important Marine Fin Fishes. British Journal of Biomedical Science. 2012;8(1):43-51.

2. Khan MAA, Khan YSA. Insect Infestation and Preventive Measures in Dry Fish Storage of Chittagong, Bangladesh. International Journal of Biological Sciences. 20011(10):963-965.

3. Musa U, Hati SS, Adamu YI, et al. Pesticides Residues in Smoked Fish Samples from North-Eastern Nigeria. Journal of Applied Sciences. 2010;10:975-980.

4. Dewi RS, Nurul-Huda G, Ahmad R. Changes in the Physicochemical Properties, Microstructure and Sensory Characteristics of Shark Dendeng Using Different Drying Methods. American Journal of Food Technology. 2011;6(2):149-157.

5. Feldhusen F. The Role of Seafood in Bacterial Foodborne Diseases Microbe Infection. 2000;2(13):1651-1660.

6. Huss HH. Assurance of Seafood Quality. FAO Fisheries Technical Paper, FAO Fisheries Technical Paper. Rome, FAO. 1993 ;(334):169.

7. Guyer S, Jemmi T. Behavior of Listeria MonocytogenesDuring Fabrication and Storage of Experimentally Contaminated Smoked Salmon. Applied and Environmental Microbiology. 1991;57(5):15231527.

8. Loncarevic STW, Danielsson-Tham M-L. Prevalence of $L$. monocytogenes and Listeria spp. In Smoked and 'gravad' fish. Acta Vet Scandinavica. 1996;37(1):8-13.

9. Peiris I P, Valladares G, Parihar VS, et al. Gravad (Gravlax) and ColdSmoked Salmon, Still a Potential Sourceof listeriosis. Inc. Journal of Foodservice. 2009;20(1):15-20.

10. Knowles E. Gravlax. Australian Gourmet Traveller. 2012;12(10):52-53.

11. Hans HH, Ababouch L, Gram L. Assessment and Management of Seafood Safety and Quality. FAO Fisheries Technical Paper. 2003;444(Rome, FAO):230.

12. Huss HH, Dalgaard P, Gram L. Microbiology of Fish and Fish Products. In Luten JB, Borresen T \& Oehlenschlager J (Eds.), Seafood from Producer to Consumer, Integrated Approach to Quality. Amsterdam: Elsevier Science Publishers. 1997;PP.20-33.

13. Nickelson II, R, Finne G. Fish, Crustaceans, and Precooked Seafood. In: Vanderzant, C. and Spilttstoesser DF(Eds.), Compendium of Methods for the Microbiological Examination of Foods. American Public Health Association (3rd edn), Washington D.C. 1992.

14. AFDO, Association of Food and Drug Officials. Cured, Salted, and Smoked Fish Establishments Good Manufacturing Practices [model code]. [York (PA)]. Association of Food and Drug Officials. 1991

15. Doyle PJ. Seafood Shelf Life as a Function of Temperature. Alaska Sea Grant Marine Advisory Program. 1995;30:1-6.

16. Giuffrida A, Valenti D, Giarratana F, et al. A New Approach to Modeling the Shelf Life of Gilthead Seabream (Sparusaurata). Int. J Food Sci Technol. 2013;48(6):1235-1242.

17. Huss HH. Quality and Changes in Fresh Fish. FAO Fisheries Technical Paper-Food and Agriculture Organization of the United Nations. Rome, FAO. 1995;348:220.

18. Simpson R, Almonacid S, Acevedo C, et al. Mathematical Model to Predict Effect of Temperature Abuse in MAP Systems Applied to Pacific Hake (Merlucciusaustralis). Journal of Food Engineering. 2003;26(5):413-434. 
19. Reddy NR, Armstrong DJ. Shelf life Extension and Safety Concerns about Fresh Fish Products Packed under MA: A review. Journal of Food safety. 1992;12(2):87-118.

20. Sivertsvik M, Jeksrud WK, Rosnes TJ. A Review of Modified Atmosphere Packaging of Fish and Fishery Products- Significance of Microbial Growth, Activities and Safety. International Journal of Food Science and Technology. 2002;37(2):107-127.

21. Emborg J, Laursen BG, Rathjen T, et al. Microbial Spoilage and Formation of Biogenic Amines on Fresh and Thawed Modified Atmosphere-Packed Salmon (Salmosalar) at $2^{\circ} \mathrm{C}$. Journal of Applied Microbiology. 2002;92(4):790-799.

22. Creed PG, Pierson BJ. Sous vide - past, present and future 3rd European Symposium on Sous Vide, Leuven. Alma Sous Vide Competence Centre. 1999.

23. Jones NR, Disney JG. Technology in Fisheries development in the Tropics, Conference Proceedings. Handling, Processing and Marketing of Tropical Fish. 1996;PP.27-31.

24. Macagnano A, Careche M, Herrero A, et al., A Model to Predict Fish Quality from Instrumental Feature. Sens. Actuators B: Chem. 2005;111112:293-298.

25. Taoukis PS, Koutsoumanis K, Nychas GJEI. Use of Time-Temperature Integrators and Predictive Modeling for Shelf life Control of Chilled Fish under Dynamic Storage Conditions. nt. J. Food Microbiol. 1999;53(1):21-31.

26. Olafsdottir G, Lauzon HL, Martinsdottir E, et al. Influence of Storage Temperature on Microbial Spoilage Characteristics of Haddock Fillets (Melanogrammusaeglefinus) Evaluated by Multivariate Quality Prediction. Int. J. Food Microbiol. 2006;111(2):112-125.

27. Parish M. How do Salt and Sugar Prevent Microbial Spoilage?" Chair of the Nutrition and Food Science Department at the University of Maryland, explains. 2006.

28. Albarracin W, Samches IC, Grau R, et al. Salt in Food Processing; Usage and Reduction: A Review. International Journal of Food Science and Technology. 2011;46(7):1329-1336.

29. Acevedo N. Water-Solids Interactions, Matrix Structural Properties and the Rate of Non-enzymatic Browning. Journal of Food Engineering. 2006;77:1108-1115.

30. Hall GM. Preservation of Fish by Curing (Drying, Salting and Smoking). Food Engineering and Biotechnology Group, Loughborough University. 1997;PP.32-73.

31. ICMSF. Micro Organisms in Foods 2. Sampling for Microbiological Analysis. Principles and Specific Applications: Blackwell Scientific Press (2nd edn). 1986;184-190.

32. AOAC. Official Methods of Analysis of AOAC International. In: Cunniff P (Ed.), AOAC Official Methods of Analysis 17th Edition Washington, DC. AOAC International. 2000.

33. Thomas PM, Pankhurst NW, Bremner HA. The Effect of Stress and Exercise on Post-Mortem Biochemistry of Atlantic Salmon and Rainbow Trout. Journal of Fish Biology. 1999;54(6):1177-1196.
34. Horner W. Preservation of Fish by Curing, Drying, Salting and Smoking. In: Hall GM (Ed.), Fish Processing Technology (2nd edn). 1997;pp.3273. London: Blackie Academic and Professional.

35. Rorvik LM. Listeria Monocytogenes in the Smoked Salmon Industry. International Journal of Food Microbiology. 2000;62(3):183-190.

36. Leroi F, Joffraud JJ. Salt and Smoke Simultaneously Effect Chemical and Sensory Quality of Cold-Smoked Salmon During $5{ }^{\circ} \mathrm{C}$ Storage Predicted Using Factorial Design. Journal of Food Protection. 2000;63(9):1222-1227.

37. FAO. Renewable Energy Source. FAO Technical Report Series (8). 1985.

38. Piggott GM, Tucker BW. Seafood: Effects of Technology on Nutrition. Marcel Dekkerinc, USA. 1990

39. Leistner L, Gould WG. Hurdle Technologies Combination Treatment for Food Stability, Safety and Quality. Kluwer/Academic Plenum Publishers. New York. 2002.

40. Ratkowsky DA, Olley J, McMeekin TA, et al. Temperature and Bacteria. Journal of Bacteriology. 1982;149:141-145.

41. Asli M, Rødbotten M, Vogt G, et al. Quality Assessment of Lightly Salted Atlantic Salmon Fillets Injected With Brine Solutions Containing Sodium Bicarbonate. Journal of Food Research. 2013;2(3):110-121.

42. Roth B, Slinde E, Arildsen J. Pre or Post Mortem Muscle Activity in Atlantic Salmon (Salmosalar).The Effect on Rigor Mortis and the Physical Properties of Flesh. Aquaculture Research. 2006;257(14):504-510.

43. FAO. Outlook, in the State of World Fisheries and Aquaculture, Editorial Production and Design Group. Food and Agriculture Organization of the United Nations, Rome. 2004:15.

44. Food and Drug Administration. Foodborne Pathogenic Microorganisms and Natural Toxins. Bad Bug Book. Second Edition. Foodborne Pathogenic Microorganisms and Natural Toxins. 2012:99-103.

45. Griffith CD, Worsfold, Mitchell R. Food Preparation, Risk Communication and the Consumer. Food Control. 1998;9:225-232.

46. ICMSF. Micro-organisms in Foods 6.Chapter 3."Blackie Academic \& Professional. London. U.K. 1998

47. Khalloufi S. Water activity of Freeze Dried Mushrooms and Berries. Department of Food Science and Nutrition, Canada. 2000;7.1-7.13.

48. Olafsdottir G, Luten J, Dalgaard P, et al. Methods to Determine the Freshness of Fish in Research and Industry. Proceedings of the Final Meeting of the Concerted Action "Evaluation of Fish Freshness" FAIR Program of the EU. International Institute of Refrigeration. 1997;20-23.

49. Sanjeev S, Surendran GH. Fate of Enterotoxigenic Staphylococci in Fish Subjected to Curing. Fishery Technology. 199633:66-68.

50. Surti T, Taylor A Ma ruf F. The Effect of Storage at Tropical Ambient Temperature on the Quality and Shelf Life of Grouper (Plectropomusmaculatus). Journal of Food Science and Technology. 2001;36(5):517-522. 